\title{
Evaluation of Plasma Ionized Magnesium Levels in Neonatal Hyperbilirubinemia
}

\author{
S. UMIT SARICI, MUHITTIN A. SERDAR, GULSEN ERDEM, AND FARUK ALPAY
}

Division of Neonatology [S.U.S., G.E.], Department of Pediatrics, Hacettepe University Faculty of Medicine Ihsan Dogramaci Children's Hospital, Ankara 06100, Turkey; and Departments of Clinical Biochemistry [M.A.S.] Pediatrics [F.A.], Gulhane Military Medical Academy, Ankara 06018, Turkey

\begin{abstract}
ABST
Plasma levels of ionized magnesium (IMg) measured by ion-selective electrode were investigated in neonatal hyperbilirubinemia by comparing the newborns with $(\geq 205 \mu \mathrm{M})$ and without $(<205 \mu \mathrm{M})$ significant hyperbilirubinemia (groups of severe and moderate hyperbilirubinemia, respectively). Serum bilirubin, plasma IMg, and ionized calcium (ICa) levels were determined in 165 healthy term newborns with nonhemolytic indirect hyperbilirubinemia during the first $10 \mathrm{~d}$ of life. Mean serum bilirubin, plasma IMg, and ICa levels were 200.1 \pm 126.5 $\mu \mathrm{M}, 0.54 \pm 0.12 \mathrm{mM}$, and $1.15 \pm 0.12 \mathrm{mM}$, respectively, in 165 newborns whose mean postnatal age was $156.1 \pm 46.5 \mathrm{~h}$, and there was a significant positive correlation between the mean serum bilirubin and plasma IMg levels $(r=0.535, p<0.001)$. Serum bilirubin levels $(304.4 \pm 83.8 \mu \mathrm{M}$ versus $94.1 \pm 54.7$ $\mu \mathrm{M})$ and plasma $\mathrm{IMg}$ levels $(0.6 \pm 0.12 \mathrm{mM}$ versus $0.49 \pm 0.1$ $\mathrm{mM})$ were significantly higher and plasma ICa levels (1.13 \pm $0.12 \mathrm{mM}$ versus $1.18 \pm 0.12 \mathrm{mM}$ ) were significantly lower in the group of severe hyperbilirubinemia $(n=83)$ when compared with the group with moderate hyperbilirubinemia $(n=82)$. Seventeen of the 83 cases of severe hyperbilirubinemia had $\mathrm{IMg}$ levels above the normal range $(\geq 0.69 \mathrm{mM})$, whereas none of the
\end{abstract}

82 cases of moderate hyperbilirubinemia had elevated IMg levels. Fifteen of the 17 with high IMg levels had bilirubin levels $>290 \mu \mathrm{M}$. Results of the present study suggest that increase in plasma IMg may be due to extracellular movement of $\mathrm{Mg}$, a principally intracellular ion, resulting from generalized cellular injury including neurons and erythrocytes. Considering neuroprotective functions and beneficial effects of $\mathrm{Mg}$ ion in improving neurologic outcome, we also may speculate the possibility of a neuroprotective role or a compensatory mechanism in $\mathrm{IMg}$ increase against emerging toxicity risk of increasing serum bilirubin levels. (Pediatr Res 55: 243-247, 2004)

$\quad$ Abbreviations
NMDA, N-methyl-D-aspartate HIE, hypoxic ischemic
encephalopathy
Mg, magnesium
IMg, ionized magnesium
G-6PD, glucose-6-phosphate dehydrogenase
ISE, ion-selective electrode
ICa, ionized calcium

Deposition of unbound bilirubin or its acid form in the neuron membrane causes permanent neuronal injury with a distinctive regional topography throughout the CNS. Considering the affinity of bilirubin molecule to phospholipids of the plasma membrane $(1-4)$, the sequence of membrane events initiated by bilirubin molecules damages all adjacent membrane-bound enzymes and receptors. However, distant plasma membrane structures such as N-methyl-D-aspartate (NMDA) receptor/ion channel complex located within neuronal membranes on the synaptic surface of neurons are disrupted as well. Increased and prolonged activation of NMDA receptor as in perinatal asphyxia and hypoxic ischemic encephalopathy (HIE) results in brain cell injury despite its physiologic roles in brain

Received October 25, 2002; accepted May 29, 2003.

Correspondence: S. Umit Sarici, M.D., Seckin Ecz. Talatpasa Bulv. 142/C, Cebeci, Dortyol-06340, Ankara, Turkey; e-mail: yresearcher@yahoo.com

DOI: 10.1203/01.PDR.0000103874.01584.F3 plasticity; neuronal growth; synaptogenesis; and development of learning, memory, and vision. However, it has been shown in newborn piglets that bilirubin also increases activation of the NMDA receptor by modifying its binding characteristics, increases the receptor's affinity for NMDA receptor antagonists, and thus results in neuronal injury (5). Bilirubin-induced neurotoxicity may share common features with HIE-induced brain injury by mechanisms mediated by the NMDA receptor $(1,2$, $5,6)$. The observations that both bilirubin-induced (6) and HIE-induced $(7,8)$ neuronal injury can be blocked by the administration of a potent NMDA receptor antagonist MK-801 (dizocilpine) further support the hypothesis that similar excitotoxic mechanisms contribute to the neuronal injury caused by both bilirubin and hypoxia.

Magnesium (Mg) ion, like MK-801, is one of the most important antagonistic regulators of the NMDA receptor/ion channel complex $(8,9)$. It protects the CNS against hypoxia and exerts its neuroprotective effects by blocking excitotoxic 
and NMDA receptor-mediated neuronal injury mechanisms (8, 10-13). Many physiologic functions of $\mathrm{Mg}$ ions seem to act against or compensate for the neurotoxic effects of bilirubin molecules $(14,15)$. Plasma levels of ionized $\mathrm{Mg}(\mathrm{IMg})$, which is thought to reflect the metabolic status of the physiologically active fraction of $\mathrm{Mg}$ truly and accurately (16), and its relationship to serum bilirubin levels in neonatal hyperbilirubinemia have not been investigated previously. In this study, we therefore wished to investigate the plasma levels of IMg in neonatal nonhemolytic hyperbilirubinemia by comparing the newborns with and without significant hyperbilirubinemia. We also studied whether there was a significant correlation between plasma IMg levels and severity of hyperbilirubinemia.

\section{MATERIALS AND METHODS}

Subjects and protocol. This study was performed at the Department of Pediatrics of Hacettepe University Faculty of Medicine. Between February 2001 and January 2002, newborns who were admitted with jaundice and who were undergoing venipuncture for various clinical indications such as suspected sepsis, screening for metabolic diseases, and/or evaluation of hyperbilirubinemia were included in the study. Only full-term, appropriate-for-gestational-age, and healthy newborns were enrolled in the study.

Newborns who had cephalohematoma, any congenital malformation, inborn errors of metabolism, or proven sepsis or infection or whose mother was antenatally administered $\mathrm{Mg}$ sulfate at any time during gestation were not included. Newborns with anemia $(\mathrm{Hb}<8.7 \mathrm{mM}$ ) or signs of hemolysis (a positive direct antiglobulin test and/or a peripheral blood smear indicative of hemolysis) or with hemolytic hyperbilirubinemia resulting from $\mathrm{Rh}, \mathrm{ABO}$, or minor blood group incompatibilities; glucose-6-phosphate dehydrogenase (G-6PD) deficiency; or erythrocyte membrane defects were excluded from the study. Birth weight, mode of delivery, sex, gestational age, Apgar score, and postnatal age of the cases were recorded. Written informed consent was obtained from the parents, and the study was approved by our local institutional ethics committee.

Measurements. Complete blood count, peripheral smear, blood group determination and $\mathrm{Rh}$ typing, direct antiglobulin test, and G-6PD activity in all cases and typing of minor blood groups in newborn-mother pairs, when indicated, were performed in newborns who received a diagnosis of and were hospitalized for significant hyperbilirubinemia.

Two blood samples (1 mL each) for determination of plasma IMg and serum bilirubin levels were obtained from infants during venipuncture. For IMg analysis, whole blood was drawn in ion-selective electrode (ISE; Lithium)-balanced heparinized and nonsiliconized Microtainer tubes (Becton Dickinson Vacutainer Systems, Cedex, France). Blood samples were either analyzed within $3 \mathrm{~h}$ or centrifuged, and the separated plasma was stored in a refrigerator at $-20^{\circ} \mathrm{C}$ for further analysis. The specimens were analyzed with ISE method in conjunction with a AVL 988-4 ISE Analyzer (AVL List GmbH Medizintechnik, Graz, Austria) considering all precautions for sample handling and processing as reported previously (17-19). The ISE method compares the electrical potential difference between two solutions that are dependent on the different concentrations of a given ion in the two solutions, and thus a patient sample is compared with a test sample. Ionized calcium (ICa) and $\mathrm{pH}$ were also measured using the same blood sample and ISE analyzer. For correction of $\mathrm{pH}$ and ionization changes resulting from storing of the blood samples, all results of IMg and ICa were expressed as normalized for a $\mathrm{pH}$ of $7.4(19,20)$. The coefficients of variation for the $\mathrm{Mg}$ and $\mathrm{Ca}$ electrodes were 3.8 and $1.7 \%$, respectively, with standard deviations of $\leq 0.02 \mathrm{mM}$ for both (19). To examine whether IMg electrode is affected by various bilirubin concentrations, we performed a test-tube study. To do this, we added three different amounts of bilirubin (final concentrations $0,85,170$, and $340 \mu \mathrm{M}$ ) to $0.5 \mathrm{mM}$ of $\mathrm{Mg}$ in saline and performed five measurements in each pooled series. The recovery values for IMg measurement at 85-, 170-, and $340-\mu \mathrm{M}$ bilirubin values were 96,95 , and $98 \%$, respectively. Serum bilirubin levels were measured by colorimetric method (diazotized sulfanilic acid reaction; Roche Diagnostics Kits, Roche Diagnostics Co, Indianapolis, IN, U.S.A.) in a Roche/Hitachi 747 autoanalyzer.

Statistical analysis. Data from cases were analyzed using SPSS for Windows 10.0 program. Correlation analysis among the different parameters of the cases was made with Pearson's correlation analysis test. Because serum bilirubin values were distributed in a wide range and we primarily aimed to investigate the relationship and correlation between IMg levels and severity of hyperbilirubinemia, cases were further divided into two groups: groups of moderate hyperbilirubinemia and severe hyperbilirubinemia on the basis of serum bilirubin level of 205 $\mu \mathrm{M}(<205 \mu \mathrm{M}$ or $\geq 205 \mu \mathrm{M}$, respectively), which has reportedly been the critical level for defining significant hyperbilirubinemia (21). Comparisons between these two groups were performed with independent sample $t$ test. Comparisons and assessment of the relationship between the plasma IMg levels above the critical level of $0.69 \mathrm{mM}$, which has reportedly been the upper limit of normal in healthy term newborns (22-24), and the critical serum bilirubin levels of significant $(\geq 205 \mu \mathrm{M})$ (21) and severe $(\geq 290 \mu \mathrm{M})(25,26)$ hyperbilirubinemia were made using $\chi^{2}$ test. Parameters with nominal values such as sex and mode of delivery were compared with $\chi^{2}$ test.

\section{RESULTS}

The study included 165 newborns whose serum bilirubin levels ranged between 8.5 and $607 \mu \mathrm{M}$. Demographic and laboratory characteristics of the cases in the study are shown in Table 1.

According to the results of the correlation analysis performed on the parameters of the cases in the study, there was a significant positive correlation between the mean serum bilirubin and plasma IMg levels $(r=0.535, p<0.001$; Fig. 1$)$. Eighty-three cases with serum bilirubin levels of $\geq 205 \mu \mathrm{M}$ and 82 cases with serum bilirubin levels of $<205 \mu \mathrm{M}$ constituted the groups of severe hyperbilirubinemia and moderate hyperbilirubinemia, respectively. Demographic and laboratory characteristics of the groups of severe and moderate hyperbilirubinemia are given in Table 2. Plasma IMg levels were 
Table 1. Demographic and laboratory characteristics of the cases in the study

\begin{tabular}{lc}
\hline Sex $($ female/male) & $74 / 91$ \\
Mode of delivery (vaginal/cesarean) & $86 / 79$ \\
Gestational age (wk)* & $39.9 \pm 1.1$ \\
Birth weight $(\mathrm{g})^{*}$ & $3244.9 \pm 429.7$ \\
Apgar score* & $9.0 \pm 0.7$ \\
Postnatal age $(\mathrm{h}) *$ & $156.1 \pm 46.5$ \\
Serum bilirubin $(\mu \mathrm{mol} / \mathrm{L})^{*}$ & $200.1 \pm 126.5$ \\
Plasma IMg $(\mathrm{mmol} / \mathrm{L})^{*}$ & $0.54 \pm 0.12$ \\
Plasma ICa $(\mathrm{mmol} / \mathrm{L})^{*}$ & $1.15 \pm 0.12$ \\
\hline
\end{tabular}

* Values are given as mean $\pm \mathrm{SD}$.

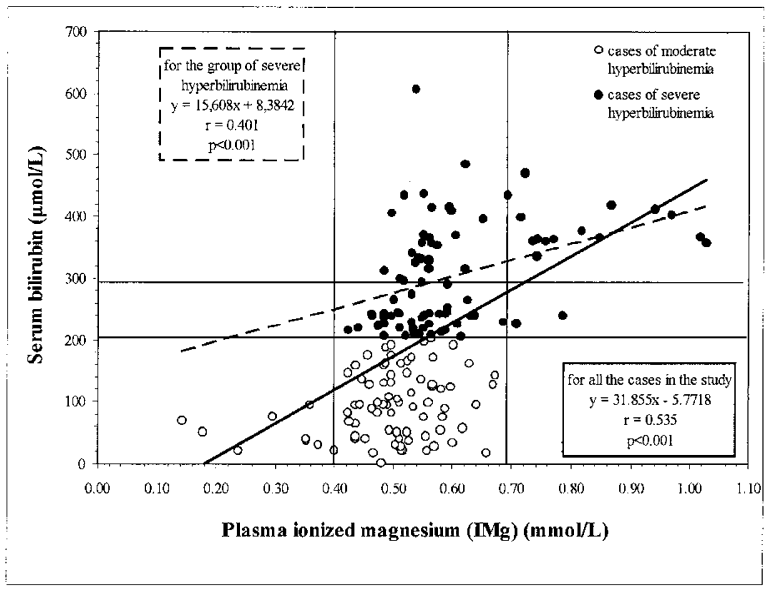

Figure 1. Distribution of the plasma IMg values of the cases with and the cases without significant hyperbilirubinemia according to the reported normal values $(0.4-0.69 \mathrm{mM})$ in healthy term newborns and to the critical serum bilirubin levels of 205 and $290 \mu \mathrm{M}$. Significant positive correlations between the serum bilirubin and plasma IMg levels in the group of severe hyperbilirubinemia and in whole of the cases also are shown.

Table 2. Demographic and laboratory characteristics of the study groups

\begin{tabular}{lccr}
\hline & $\begin{array}{c}\text { Group of Severe } \\
\text { Hyperbilirubinemia } \\
(n=83)\end{array}$ & $\begin{array}{c}\text { Group of Moderate } \\
\text { Hyperbilirubinemia } \\
(n=82)\end{array}$ & $\begin{array}{c}p \\
\text { value }\end{array}$ \\
\hline Sex (female/male) & $35 / 48$ & $39 / 43$ & \\
Mode of delivery & $43 / 40$ & $43 / 39$ & \\
$\quad$ (vaginal/cesarean) & & & \\
Gestational age $(\mathrm{wk}) *$ & $40.1 \pm 1.2$ & $39.6 \pm 1.1$ & 0.724 \\
Birth weight $(\mathrm{g}) *$ & $3223.7 \pm 415.5$ & $3266.3 \pm 445$ & 0.525 \\
Apgar score* & $9.0 \pm 0.8$ & $9.1 \pm 0.7$ & 0.258 \\
Postnatal age $(\mathrm{h})^{*}$ & $151.4 \pm 51.8$ & $160.8 \pm 40.2$ & 0.193 \\
Serum bilirubin $(\mu \mathrm{mol} / \mathrm{L})^{*}$ & $304.4 \pm 83.8$ & $94.1 \pm 54.7$ & $<0.001$ \\
Plasma IMg $(\mathrm{mmol} / \mathrm{L})^{*}$ & $0.6 \pm 0.12$ & $0.49 \pm 0.1$ & $<0.001$ \\
Plasma ICa $(\mathrm{mmol} / \mathrm{L})^{*}$ & $1.13 \pm 0.12$ & $1.18 \pm 0.12$ & 0.016 \\
\hline
\end{tabular}

* Values are given as mean $\pm \mathrm{SD}$.

significantly higher $(0.6 \pm 0.12 \mathrm{mM}$ versus $0.49 \pm 0.1 \mathrm{mM} ; p$ $<0.001)$ and ICa levels were significantly lower $(1.13 \pm 0.12$ $\mathrm{mM}$ versus $1.18 \pm 0.12 \mathrm{mM} ; p=0.016)$ in the cases with significant hyperbilirubinemia when compared with the cases without significant hyperbilirubinemia. Plasma IMg values showed distribution in a wide range, and ICa values were in normal ranges in the group of severe hyperbilirubinemia, although the mean plasma level of ICa was significantly lower than that of the group of moderate hyperbilirubinemia (Fig. 2).

Correlation analysis within the group of severe hyperbilirubinemia demonstrated a significant positive correlation be-
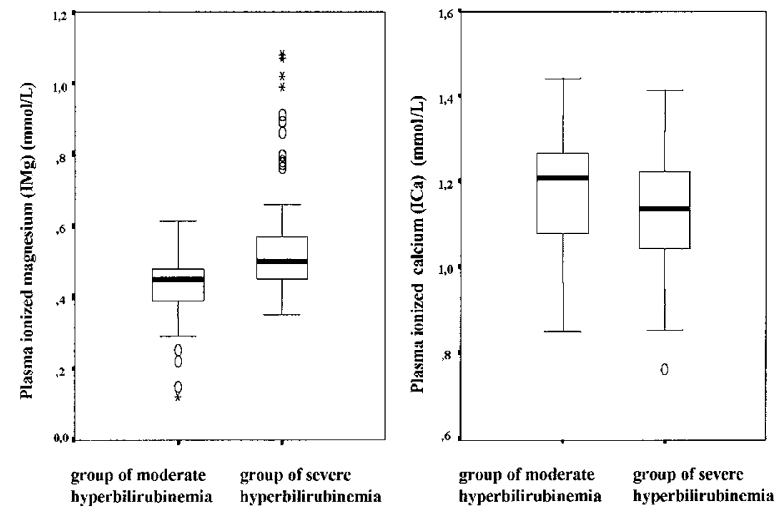

Figure 2. Distribution of the plasma IMg and ICa values in the groups of severe hyperbilirubinemia and moderate hyperbilirubinemia.

tween the plasma IMg levels and severity of hyperbilirubinemia $(r=0.401, p<0.001)$. Like the results of the correlation analysis in all of the cases in the study, these results also indicated that plasma IMg levels increased with increasing serum bilirubin levels (Fig. 1). Seventeen of the 83 cases of severe hyperbilirubinemia had IMg levels above the normal range $(\geq 0.69 \mathrm{mM})$, whereas none of the 82 cases of moderate hyperbilirubinemia had elevated IMg levels (Fig. 1). When we analyzed the distribution of the cases with high $(\geq 0.69 \mathrm{mM})$ plasma IMg values $(n=17)$ according to the critical serum bilirubin level of severe hyperbilirubinemia $(290 \mu \mathrm{M}), 35.7 \%$ of the cases with serum bilirubin levels of $\geq 290 \mu \mathrm{M}$ had high plasma IMg values, whereas only $1.6 \%$ of the cases with serum bilirubin levels of $<290 \mu \mathrm{M}$ had high plasma IMg values (Fig. 1).

\section{DISCUSSION}

Although the blocking and modulating effects of $\mathrm{Mg}$ ions on NMDA receptor/ion channel complex have been well demonstrated $(8,9)$ and its role and neuroprotective effects in the pathophysiology of HIE have been investigated before (8, 10-13), the relationship between $\mathrm{Mg}$ and neonatal hyperbilirubinemia has not been investigated in detail. In the present study, performed on newborns with varying degrees of hyperbilirubinemia, we demonstrated a positive correlation between plasma IMg values and severity of hyperbilirubinemia and significantly higher plasma IMg levels in the group of severe hyperbilirubinemia when compared with the group of moderate hyperbilirubinemia. These results suggest that increases in plasma IMg may be due to extracellular movement of intracellular $\mathrm{Mg}$ resulting from cellular injury of neurons and erythrocytes. Indeed, bilirubin toxicity after the increase of serum bilirubin values to toxic levels not only is limited to neurons but also may cause generalized cellular injury (25). Accordingly, in a study performed on pediatric intensive care patients (27), hypermagnesemia has been proposed to be a poor prognostic criterion being associated with critical cellular injury. Increased levels of plasma Mg have been demonstrated in a few other situations in which generalized cellular injury occurs as a result of perinatal asphyxia and $\operatorname{HIE}(28,29)$ and to neonatal hypoxemia and acidosis $(30,31)$. In the present study, the increase of IMg levels was correlated with the severity of 
hyperbilirubinemia, especially in the cases with serum bilirubin levels of $\geq 290 \mu \mathrm{M}$, the accepted threshold level for toxic hyperbilirubinemia $(25,26)$. This finding also suggests the possibility of a neuroprotective role or a compensatory mechanism in IMg increase against emerging toxicity risk of increasing serum bilirubin values.

Measurement of serum or plasma total $\mathrm{Mg}$ does not correctly reflect the free or ionized intracellular form of $\mathrm{Mg}$ that is physiologically active, because $\mathrm{Mg}$ is principally an intracellular ion and only $<1 \%$ of total body $\mathrm{Mg}$ is found in the extracellular (blood) compartment $(14,16,22)$. ISE is a relatively new method that permits IMg to be measured rapidly and accurately in very small samples of body fluids (16-18), and there are only a few studies performed with this method in children and especially in newborns $(22-24,32,33)$. In two studies performed on pediatric intensive care patients (32) and 22 newborns with hypomagnesemia (33), it was shown that serum total $\mathrm{Mg}$ levels may not correlate with IMg levels and that IMg measurement best provides a more relevant assessment of $\mathrm{Mg}$ homeostasis. In one of the initial studies conducted by using ISE method in umbilical cord blood samples, Handwerker et al. (24) reported umbilical venous IMg levels (0.49$0.53 \mathrm{mM})$ a little higher than umbilical arterial ones $(0.46-0.5$ $\mathrm{mM})$. In another study aiming to determine normative data in healthy term newborns (22), IMg levels were investigated in umbilical venous blood of 30 newborns at birth and in peripheral venous blood of 32 newborns at $24 \mathrm{~h}$ of life, and normal ranges of IMg in both groups reportedly were between 0.4 and $0.56 \mathrm{mM}$. A reference interval for IMg of $0.41-0.69 \mathrm{mM}$ was reported for 63 term newborns in a study presenting the reference values of normal serum IMg in healthy and premature newborns during the first $72 \mathrm{~h}$ of life (23). In the present study including 165 term, appropriate-for-gestational age, and healthy-except for hyperbilirubinemia-newborns, mean plasma IMg levels measured during the first $10 \mathrm{~d}$ of life were $0.54 \pm 0.12 \mathrm{mM}$ and $0.49 \pm 0.1 \mathrm{mM}$ in the total study group and in the cases with moderate hyperbilirubinemia, respectively. Although these levels are similar and close to those in the previously published studies on newborns, the relatively wider ranges in our study may have resulted from the mean postnatal age $(156.1 \pm 46.5 \mathrm{~h})$ of the cases, considering physiologic changes in $\mathrm{Mg}$ levels during the first week of life. Previously published neonatal IMg studies (22-24) have been conducted in exclusively healthy newborns during the first 24-72 h of life. The high serum bilirubin levels also may have contributed to greater variability of IMg; high IMg levels $(0.6$ $\pm 0.12 \mathrm{mM}$ ) in the group of severe hyperbilirubinemia in our study further supports this hypothesis.

Although NMDA receptor/ion channel complex has recently been associated with pathophysiology of bilirubin neurotoxicity, only a few studies (34-37) have focused on the role of $\mathrm{Mg}$ in the cause of neonatal hyperbilirubinemia in an attempt to reveal the relationship between hyperbilirubinemia and $\mathrm{Mg}$ ions, one of the most important inhibitor regulators of the NMDA channel. In their first study, Tuncer et al. (34) reported lower serum total $\mathrm{Mg}$ concentrations in both umbilical cord and maternal blood of newborns with hyperbilirubinemia when compared with normal newborns, and they postulated that hypomagnesemia results from intracellular shift of $\mathrm{Mg}$ ion. In their next study, Tuncer et al. (35) investigated the serum levels of zinc, copper, and total Mg in umbilical cord blood and peripheral venous blood of newborns with nonhemolytic hyperbilirubinemia, and they reported lower umbilical and neonatal serum zinc and total $\mathrm{Mg}$ concentrations in both newborns with moderate hyperbilirubinemia and newborns with severe hyperbilirubinemia undergoing exchange transfusion in comparison with newborns without hyperbilirubinemia. They speculated that maternal gestational malnutrition may have caused maternal and neonatal hypomagnesemia by negatively affecting enzymes in bilirubin metabolism and antioxidant enzymes in erythrocytes, thus leading to significant neonatal indirect hyperbilirubinemia. The differences in Mg levels (decreased versus increased) between these two studies and our study may be due either to the method used $(22,32,33)$ or to the differences in serum bilirubin levels and ages of the newborns among these studies.

In another study investigating the relationship between neonatal hyperbilirubinemia and various trace elements (36), serum total $\mathrm{Mg}$ levels were found significantly lower in 30 newborns with hemolytic hyperbilirubinemia when compared with healthy control subjects. Pintov et al. (37) investigated the value of umbilical cord zinc, copper, and total $\mathrm{Mg}$ measurements in predicting the future (48th hour) development of hyperbilirubinemia, and they reported no differences in the levels of these trace elements and $\mathrm{Mg}$ between 29 newborns with a serum bilirubin level of $\geq 136.8 \mu \mathrm{M}$ (mean, $186.4 \pm 41$ $\mu \mathrm{M})$ and 61 newborns with a serum bilirubin level of $<136.8$ $\mu \mathrm{M}$ (mean, $106 \pm 17.1 \mu \mathrm{M}$ ) at the 48th hour of life. The authors regarded the measurement of these elements in cord blood of no value in predicting the development of significant hyperbilirubinemia. However, the mean serum bilirubin levels in that study were in the range of physiologic hyperbilirubinemia, and these serum bilirubin levels may not be high enough to reveal the relationship between $\mathrm{Mg}$ and hyperbilirubinemia. In our study, the mean serum bilirubin level (304.4 \pm $83.8 \mathrm{mg} / \mathrm{dL}$ ) of the group of severe hyperbilirubinemia was significantly higher than that $(94.1 \pm 54.7 \mathrm{mg} / \mathrm{dL})$ of the group of moderate hyperbilirubinemia. The present study is the first to assess the relationship between serum bilirubin and plasma IMg levels using ISE method in newborns with such (significantly) high serum bilirubin levels within the first $10 \mathrm{~d}$ of life.

\section{CONCLUSION}

In conclusion, both the positive correlation between plasma $\mathrm{IMg}$ levels and severity of hyperbilirubinemia in newborns who had a wide range of serum indirect bilirubin levels (8.5$607 \mu \mathrm{M})$ and the presence of significantly higher plasma $\mathrm{IMg}$ levels in newborns with severe ( $\geq 205 \mu \mathrm{M})$ hyperbilirubinemia when compared with newborns with lower levels of bilirubin $(<205 \mu \mathrm{M})$ suggest that increase in plasma IMg may be due to extracellular movement of $\mathrm{Mg}$, a principally intracellular ion, resulting from generalized cellular injury including neurons and erythrocytes. Considering neuroprotective functions and beneficial effects of $\mathrm{Mg}$ ion in improving neurologic outcome, we also may speculate the possibility of a neuroprotective role 
or a compensatory mechanism of increased IMg levels to reduce bilirubin toxicity. Measurement of $\mathrm{IMg}$, which is thought to reflect the actual metabolic status of $\mathrm{Mg}$ ion accurately, in hemolytic hyperbilirubinemias such as $\mathrm{ABO}$ and $\mathrm{Rh}$ incompatibilities, in which significant erythrocyte destruction is prominent, would help to determine whether increases of IMg in neonatal hyperbilirubinemia are due to cellular injury or results from a neuroprotective role and/or a compensatory mechanism. Determination of the exact pathophysiologic process responsible for elevation of $\mathrm{IMg}$ levels and demonstration of the relationship and interactions between IMg and hyperbilirubinemia will make it possible to use cord blood or early postnatal IMg measurements in predicting the development of significant hyperbilirubinemia and to question the value of $\mathrm{Mg}$ treatment in the therapy of neonatal hyperbilirubinemia.

Acknowledgment. We gratefully thank our residents, who sincerely did their best in conducting every phase of the study.

\section{REFERENCES}

1. Volpe JJ 1995 Bilirubin and brain injury. In: Volpe JJ (ed) Neonatal Neurology. WB Saunders, Philadelphia, pp 490-514

2. Cashore WJ 1998 Bilirubin metabolism and toxicity in the newborn. In: Polin RA Fox WW (eds) Fetal and Neonatal Physiology. WB Saunders, Philadelphia, pp $1493-1498$

3. Bradlit D 1990 How bilirubin gets into the brain. Clin Perinatol 17:449-465

4. Brodersen R 1979 Bilirubin solubility and interaction with albumin and phospholipid. J Biol Chem 254:2364-2369

5. Hoffman DJ, Zanelli SA, Kubin J, Mishra OP, Delivoria-Papadopoulos M 1996 The in vivo effect of bilirubin on the N-methyl-D-aspartate receptor/ion channel complex in the brains of newborn piglets. Pediatr Res 40:804-808

6. McDonald JW, Shapiro SM, Silverstein FS, Johnston MV 1990 Excitatory amino acid neurotransmitter systems contribute to the pathophysiology of bilirubin encephalopathy. Ann Neurol 28:413A(abstr)

7. Hoffman DJ, McGowan JE, Marro P, Mishra OP, Delivoria-Papadopoulos M 1994 Hypoxia-induced modification of the N-methyl-D-aspartate (NMDA) receptor in the brain of newborn piglets. Neurosci Lett 167:156-160

8. Johnston M, McDonald M, Chen C, Trescher W 1991 Role of excitatory amino acid receptors in perinatal hypoxic-ischemic brain injury. In: Meldrum BS, Moroni F, Simon RP, Woods JH (eds) Excitatory Amino Acids. Raven Press, New York, pp $711-716$

9. Ascher P, Nowak L 1987 Electrophysiological studies on NMDA receptors. Trends Neurosci 10:284-288

10. Hoffman DJ, Marro PJ, McGowan JE, Mishra OP, Delivoria-Papadopoulos M 1994 Protective effect of $\mathrm{MgSO}_{4}$ infusion on NMDA receptor binding characteristics during cerebral cortical hypoxia in the newborn piglet. Brain Res 644:144-149

11. McDonald JW, Silverstein FS, Johnston MV 1990 Magnesium reduces N-methyl-Daspartate (NMDA)-mediated brain injury in perinatal rats. Neurosci Lett 109:234238

12. Marret S, Gressens P, Gradisseux JF, Evrard P 1995 Prevention by magnesium of excitotoxic neuronal death in the developing brain. Dev Med Child Neurol 37:473484

13. Thordstein M, Bagenholm R, Thiringer K, Kjellmer I 1993 Scavengers of free oxygen radicals in combination with magnesium ameliorate perinatal hypoxic-ischemic brain damage in the rat. Pediatr Res 34:23-26
14. Aikawa JK 1981 Magnesium: its biological significance. CRC Press, Boca Raton, pp $21-56$

15. Brierly GP, Jung DW, Altschuld RA 1987 Magnesium and mitochondrial ion transport. In: Altura BM, Durlach J, Seelig MS (eds) Magnesium in Cellular Processes and Medicine. Karger, Basel, pp 89-105

16. Altura BM 1994 Introduction: importance of Mg in physiology and medicine and the need for ion selective electrodes. Scand J Clin Lab Invest Suppl 217:5-9

17. Altura BT, Shirey TL, Young CC, Hiti J, Dell'Orfano K, Handwerker SM, Altura BM 1992 A new method for the rapid determination of ionized $\mathrm{Mg}^{2+}$ in whole blood, serum and plasma. Methods Find Exp Clin Pharmacol 14:297-304

18. Altura BT, Shirey TL, Young CC, Dell'Orfano K, Hiti J, Welsh R, Yeh Q, Barbour RL, Altura BM 1994 Characterization of a new ion selective electrode for ionized magnesium in whole blood, plasma, serum and aqueous samples. Scand J Clin Lab Invest 54(suppl 217):21-36

19. Instruction Manual 1997 AVL 988-4 ISE Analyzer Medical Instruments. AVL Lis GmbH Medizintechnik, Graz, Austria, pp 7/1-9/1

20. Zoppi F, Cristalli C 1998 Ionized magnesium in serum and ultrafiltrate: $\mathrm{pH}$ and bicarbonate effect on measurements with the AVL 988-4 Electrolyte Analyzer. Clin Chem 44:668-671

21. Kliegman RM 1996 Jaundice and hyperbilirubinemia in the newborn. In: Behrman RE, Kliegman RM, Arvin AM (eds) Nelson Textbook of Pediatrics. WB Saunders, Philadelphia, pp 493-499

22. Cook LA, Mimouni FB 1997 Whole blood ionized magnesium in the healthy neonate J Am Coll Nutr 16:181-183

23. Marcus JC, Valencia GB, Altura BT, Cracco RQ, Jean-Baptiste D, Sinha K, Altura BM 1998 Serum ionized magnesium in premature and term infants. Pediatr Neurol 18:311-314

24. Handwerker SM, Altura BT, Royo B, Altura BM 1993 Ionized serum magnesium levels in umbilical cord of normal pregnant women at delivery: relationship to calcium, demographics and birth-weight. Am J Perinatol 10:392-397

25. Dennery PA, Seidman DS, Stevenson DK 2001 Neonatal hyperbilirubinemia. N Eng J Med 344:581-590

26. American Academy of Pediatrics, Provisional Committee for Quality Improvement and Subcommittee on Hyperbilirubinemia 1994 Practice parameter: management of hyperbilirubinemia in the healthy term newborn. Pediatrics 94:558-565

27. Broner CW, Stidham GL, Westenkirchner DF, Tolley EA 1990 Hypermagnesemia and hypocalcemia as predictors of high mortality in critically ill pediatric patients. Crit Care Med 18:921-928

28. Ilves P, Kiisk M, Soopöld T, Talvik T 2000 Serum total magnesium and ionized calcium concentrations in asphyxiated term newborn infants with hypoxic-ischaemic encephalopathy. Acta Paediatr 89:680-685

29. Engel RR, Elin RJ 1970 Hypermagnesemia from birth asphyxia. J Pediatr 77:631637

30. Olofsson K, Matthiesen G, Rudnicki M 2001 Whole blood ionized magnesium in neonatal acidosis and preterm infants: a prospective consecutive study. Acta Paediatr 90:1398-1401

31. Sarici SU, Serdar MA, Erdem G, Alpay F, Tekinalp G, Yurdakok M, Yigit S, Gokcay E 2004 Plasma ionized magnesium levels in neonatal respiratory distress syndrome. Biol Neonate (in press)

32. Fiser RT, Torres A Jr, Butch AW, Valentine JL 1998 Ionized magnesium concentrations in critically ill children. Crit Care Med 26:2048-2052

33. Maggioni A, Orzalesi M, Mimouni FB 1998 Intravenous correction of neonatal hypomagnesemia: effect on ionized magnesium. J Pediatr 132:652-655

34. Tuncer M, Yenice A, Özand P 1972 Serum Mg, Ca, total protein levels in maternal and cord blood and its clinical significance. Turk J Pediatr 14:13-22

35. Tuncer M, Demirsoy S, Özsoylu S, Erdem G 1982 The significance of zinc, copper and magnesium levels of maternal cord and newborns sera in hyperbilirubinemia of unknown etiology. Turk J Pediatr 24:227-233

36. Misra PK, Kapoor RK, Dixit S, Seth TD 1988 Trace metals in neonatal hyperbilirubinemia. Indian J Pediatr 25:761-764

37. Pintov S, Kohelet D, Arbel E, Goldberg M 1992 Predictive inability of cord zinc, magnesium and copper levels on the development of benign hyperbilirubinemia in the newborn. Acta Paediatr 81:868-869 